\title{
The world authority
}

Kenneth Jaffe, MD

Editor's note: Readers' Forum is a department for correspondence from readers that is not in response to articles published in CURRENT PSYCHIATRY. All submissions to Readers' Forum undergo peer review and are subject to editing for length and style. For more information, contact letters@currentpsychiatry.com.

$t$ was the late 1970s. She arrived by limousine; an attractive young woman, "Jasmine," daughter of one of the richest men in the country. She was wearing a silk blouse and was adorned with an abundance of jewelry: large earrings, a necklace, and rings on nearly every finger. She smiled broadly when I introduced myself, shook her hand, and ushered her into my office.

She moved quickly and spoke in a rapid and pressured manner. She complained of poor sleep, mood swings, and racing thoughts. I began to ask her questions. "Have you used cocaine recently?" "What about Ritalin or amphetamines?" "Do you take prednisone or any other steroids?" "Do you have thyroid disease?" "Do you or anyone in your family have a history of manic depressive illness? Who? Have they ever required hospitalization for its treatment?"

"Well, doctor, what do you think?" she asked.

"I think that you probably have manic depressive illness and that you are currently having a manic episode. You should go into the hospital and begin treatment with lithium."

"Who is the authority on this illness?" she asked.
“...The US authority or the world authority?" I replied.

"The world authority" she answered.

"Probably Professor Mogens Schou in Copenhagen," I said.

"I'll go see what he thinks," she responded.

"Okay, you do that," I replied.

When she left, I thought, "What a grandiose young woman. I doubt I'll hear from her again."

Three days later I received an unusual phone call.

"Dr. Jaffe, this is the long-distance operator, will you hold for Dr. Schou?"

"Of course," I replied.

"Dr. Jaffe, I'm here with your patient, a charming young woman. I told her that I am in complete agreement with your diagnosis and treatment plan. She will be flying home tomorrow."

A few days after she arrived home, I had Jasmine hospitalized under my care at one of the local psychiatric units. She stabilized nicely on lithium and tolerated it well. She remained there for about 3 weeks and was then discharged. I began seeing her in my office for weekly visits. After a few months we started meeting every 2 weeks, and eventually monthly.

She was doing well. Her mood swings were now mild and infrequent. Her sleep had normalized. Most important, she felt a lot more in control of her life.

Jasmine offered me a small window into the world of the super-rich and powerful. Basically, what I learned was that they are just like the rest of us, only more so. All the money provides both the opportunity to do
Dr. Jaffe is Distinguished Life Fellow, American Psychiatric Association, South Hadley, Massachusetts.

Disclosure

The author reports no financial relationships with any companies whose products are mentioned in this article, or with manufacturers of competing products.

doi: $10.12788 /$ cp.0174

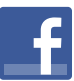

Discuss this article at www.facebook.com/ MDedgePsychiatry 
Clinical Point

Jasmine offered

me a small window

into the world of

the super-rich and

powerful a lot more good as well as to get into a lot more trouble. When a middle-class person gets manic and goes on a spending spree, they may blow a few hundred dollars on lottery tickets and perhaps a thousand dollars on clothing or gifts they don't need. When the very rich do this, they buy airplanes, Ferraris, and vacation homes.

Jasmine and her siblings were often pestered-usually by acquaintances, but sometimes by friends-for favors, usually loans, jobs, or introductions to other famous or powerful people. Jasmine turned out to be a lovely young woman, kind, generous, loyal to her friends, and with a fine sense of humor. Getting to know her well helped dispel some of my prejudices about the adult children of the super-rich. I had incorrectly assumed that she would be quite spoiled and entitled.

After working together for approximately 2 years, we said our goodbyes because I was moving to a different part of the country. She thanked me for helping her get well. I asked her if there was anything in particular that she found most helpful. She surprised me when she answered so quickly.

"Yes. When you come from a very wealthy family, most people want something from you. You never wanted anything from me except my honesty," she said.

I thanked Jasmine for her gift. 